\title{
Bovine trypanosomosis in three districts of Southwest Oromia, Ethiopia
}

\author{
Tilahun Ayele Denu ${ }^{1}$, Yilkal Asfaw ${ }^{2}$ and Yacob HailuTolossa ${ }^{2}$ \\ ${ }^{1}$ Ethiopian Ministry of Science and Technoloy, P.O.Box 19917, Addis Ababa, Ethiopia \\ ${ }^{2}$ School of Veterinary Medicine, Addis Ababa University, P. O. Box 34, Debre Zeit, Ethiopia \\ *Corresponding author: Tilahun Ayele. E-mail: teamworke2011@gmail.com
}

\begin{abstract}
A study was carried out from September 2007 to March 2008 to determine the prevalence of trypanosomosis and the apparent tsetse densities and other biting flies as well as to evaluate community awareness about the disease and its control method in three districts of west Shoa zone in Oromia. From a total of 1200 animals examined, (600 in the late rainy and 600 in the dry seasons) the prevalence of trypanosomosis was found to be $33.5 \%$ and $17.83 \%$ in the late rainy and dry seasons, respectively. There was a statistically significant difference in prevalence was observed $(p<0.05)$ between the two seasons. The mean PCV values of the parasitaemic and aparasitaemic animals during the late rainy season were $20.19 \%$ and $26.75 \%$ while during the dry season $18.75 \%$ and $23.97 \%$, respectively. A fly-survey was conducted by using 90 monoconical pyramidal traps and revealed that three tsetse species, namely G. pallidipes, G. m. submorsitans and G.f. fuscipes were found along with other biting flies (tabanids and muscids) in the study area. The apparent densities of tsetse flies were significantly different $(p<0.05)$ during the two study. The overall apparent densities of tsetse flies were found to be 2.87 fly/trap/day (95\% CI $=1.04-5.77 \%)$ and 1.26 flay/tap/day $(95 \% \mathrm{CI}=1.17-2.07 \%)$ in late rainy and dry seasons, respectively. G. f. fuscipes and G. pallidipes appear to be the dominant tsetse species in the study area. The proportion of female tsetse flies caught was higher in both seasons. The apparent density of biting flies (tabanids and muscids) was significantly higher $(\mathrm{p}<0.05)$ in the late rainy season (1.49 fly/trap/day, $18.66 \mathrm{fly} /$ trap/day) than the dry season ( $0.77 \mathrm{fly} /$ trap/day, 15.04 fly/trap/day) respectively. Poor infrastructure, absence of trypanosomosis and vector control activities in the area have worsen the situation and hence require professional intervention.
\end{abstract}

Keywords: Epidemiology, Bovine, trypanosomosis, tsetse species, biting flies, Ethiopia

http://dx.doi.org/10.4314/evj.v16i1.3 


\section{Introduction}

Trypanosomosis is the widespread protozoan disease complex affecting cattle and other wide range of hosts, including humans in the sub-Saharan Africa. The course of the disease may run from a chronic long lasting to an acute and rapidly fatal one depending on the vector-parasite-host interactions, characterized mainly by intermittent fever, progressive anaemia and loss of condition of susceptible hosts which if untreated leads to heavy mortalities (Bourn, 2001).

African Animal Trypanosomosis is a disease complex caused by Trypanososma congolense, $T$. vivax and $T$. bruceior mixed transmitted principally by tsetse flies. In Ethiopia the vector fly occupied approximately $220,000 \mathrm{~km}^{2}$ of area of fertile land and about 23.15 million livestock populations were at risk to contract the diseases (MOA, 1995). Trypanososmosis is one of the most significant and costly disease in Ethiopia hindering the effort made for foodsufficiency (Getachew Abebe, 2005).

Bovine trypanosomosis is the most important disease in the vast part of Oromia region among of which Ameya and Goro districts are known with heavy mortalities of cattle presumably due to trypanososmosis (OARDB, 2005 and ARDOSWSHZ, 2007), however, information is not yet available on the status of the disease in these districts except serious complaints raised from the farmers on the increased death rate of cattle for the last some years. Therefore, the major objectives of the present study were to determine seasonal prevalence of bovine trypanosomosis and characterize the apparent density, seasonal distribution and species of tsetse and other biting flies and thereby establish potential risk factors associated with the vector and the diseases.

\section{Materials and Methods}

\section{Study area}

The present study was conducted in six peasant associations (PAs) namely, Burka and Adami; Arba-saden and Mari-magari and Robahi and Gimbi selected from Goro, Ameya and Kota districts, respectively, located $205 \mathrm{Kms}$ to the Southwest of Addis Ababa. The altitude of the districts ranges from 1500 to 1700 m.a.s.l receiving an average annual rainfall of $1200-1500 \mathrm{~mm}$ and the average annual temperature is $27^{\circ} \mathrm{C}$ (ARDOSWSHZ, 2007). 


\section{Study animals}

The study population in the constituted 6700 indigenous zebu cattle managed under smallholder mixed crop-livestock farming system (ARDOSWSHZ, 2007). They are kept under traditional extensive husbandry system with communal grazing and watering points.

\section{Sampling method and sample size}

The sampling method applied in the present study was a multi stage random sampling. The three districts namely Goro Ameya and Kota were selected purposely based on the extent of the existing problems, the complaints of farmers and the level of medium to high tsetse challenge in the areas. The subjects have been selected randomly from the population up to the householdcattle level whereby all the animals in the selected areas had equal chances to be selected for this study. The sample size was determined using Winepiscope 2.0: improved epidemiological soft ware for veterinary medicine based on the expected prevalence rate of $20 \%$ and absolute desired precision of $5 \%$ at confidence level of 95\% study (Thrusfield, 1995). As a result, a total of 843 animals were needed to be sampled in both seasons. But in case of multi stage random sampling the larger the sample size the more accurate the result will be. Therefore, in order to increase the representativeness of study animals, sample size of 1200 animals were considered. Thus, the optimum sample size required for trypanosomosis prevalence study was a total of 1200 animals (600 in late rainy season and 600 in the dry season).

\section{Study design}

The methodologies included in this study were questionnaire survey, entomological and parasitological studies.

Questionnaire survey: a total of 300 randomly selected and volunteer farmers from the six PAs were interviewed about the occurrence of tsetse and trypanosomosis, livestock constraints, livestock management and herd structure, use and source of trypanocidal drugs and method adopted by farmers for the control of the disease and vector.

Entomological Survey: to assess the apparent densities, seasonal distributions and species of tsetse flies and other biting flies were studied. The entomological data were collected twice in late rainy and dry seasons. Mono-conical traps baited with acetone and three-week-old cow urine (Brightwell et al., 1992) were used to assess the fly density. Site selection was done to include suitable 
tsetse habitats like savannah area, river valleys, livestock grazing areas and watering points and wild game reserve areas.

Ninety mono-conical pyramidal traps 45 in each season were deployed early in the morning and maintained in position for $24 \mathrm{hrs}$ at six different sites in late rainy and in dry seasons at the same trapping sites. The cages from these traps were emptied daily. Caught tsetse flies and other biting flies were counted and identified according to the method described by Wall and Shearer (1997). Live flies have been dissected for trypanosome detection using the methods of Lloyd and Johnson, (1924).

\section{Parasitological studies}

The blood samples collected from 1200 cattle (600 during late rainy and 600 during dry season) were used to determine the seasonal prevalence of bovine trypanosomosis. Parasitological examination was conducted using the Giemsa stained thin blood smear and buff coat /phase contrast/ dark ground technique (BCT) as described by (Murray et al., 1977). The PCV of the animals were also determined.

\section{Data analysis}

Parasitological data analyzed by applying chi-square test to evaluate the prevalence of trypanosomosis in different peasant associations as well as to determine the association with different variables like age, sex and seasons. Data collected on PCV values were analyzed by two sample t-test to compare the mean PCV values of parasitaemic and aparasitaemic animals. Vector survey data were analyzed by using ANOVA to compare seasonal density and mean catches. In all cases differences between parameters have been tested for significance at probability levels of 0.05 or less. The result of the questionnaire survey was analyzed by using descriptive statistics to compute or calculate frequency of responses and percentage to summarize the data.

\section{Results}

\section{Questionnaire survey}

About $100 \%$ of the respondents' livelihood depends on mixed crop livestock production system. Therefore, in the study areas livestock are the integral part of agricultural activity and are used as food, source of income and for transport purposes. The composition of livestock species in the study areas were cattle $(80 \%)$, small ruminants (15\%) and equines (5\%). The average numbers of cattle 
were 3 to 5 cattle/household and the cultivated land was 2 hectares/household level.

The results of the questionnaire survey revealed that the main constraints to the livestock development included livestock diseases, shortage of grazing lands and watering points during the dry season and lack of modern veterinary services. Based on the interview, the main livestock diseases in the order of importance were trypanosomosis, anthrax, internal and external parasitosis, pasteurellosis, blackleg, lumpy skin disease and contagious bovine pleuropneumonia. Forty-four per cent of the respondents were aware of tsetse flies as transmitters of animal trypanosomosis.

The analysis of the answers to the questionnaire survey showed that chemotherapy was the only approach (100\%) towards the control of disease. From the total interviewed, about $65 \%$ of the respondents have treating their animals using trypanocidal drugs, as a sole means of control and managing the disease. About $35 \%$ of the respondents have reported that they were using as a treatment different types of trypanocidal drugs but buy from illegal traders on market days and these illegally smuggled trypanocidal drugs in the study area are called "Shiro" by the local community. Farmers themselves treated about $70 \%$ of the animals. The diminazene aceturate (Berenil) and isometamidium chloride (Samorine) were the commonly used drugs for treatment.

Concerning knowledge of disease transmission, $60 \%$ of the farmers responded that biting flies (tabanids and muscids) and other flies identified as small in size, brown in colour which bites their animals while grazing and watering in the forest and savanna vegetation types, the tsetse flies are responsible, while $40 \%$ do not know anything about the vector for trypanosomosis.

\section{Vector studies}

A total of 3385 flies were caught in the late rainy and dry season. By deploying 45 mono-conical traps in each season 1944 and 1441 flies were caught in the late rainy and dry seasons, respectively (Table 1). The tsetse flies found during the study period were Glossina pallidipes, Glossina m. submorsitans, G. f. fuscipes and other biting flies like G. tabanids and muscids groups were also caught along with the tsetse flies and in areas where tsetse flies were not caught. 
Table 1: Different flies caught in the late rainy and dry seasons in the study area

\begin{tabular}{lcccc}
\hline Season & Tsetse fly (\%) & \multicolumn{2}{c}{ Biting flies \% } & Total \\
\cline { 3 - 4 } & & Tabanids (\%) & Muscids (\%) & \\
\hline Late rainy & $243(12.5)$ & $126(6.48)$ & $1575(81.02)$ & 1944 \\
Dry Season & $107(7.43)$ & $65(4.51)$ & $1269(88.06)$ & 1441 \\
Total & $350(9.98)$ & $191(5.49)$ & $2844(84.54)$ & 3385 \\
\hline
\end{tabular}

Of the total fly catch tsetse flies accounted for $12.5 \%$ and $7.43 \%$ ) while tabanids accounted for $6.48 \%$ and $4.51 \%$ and Muscids covers $81.02 \%$ and $88.06 \%$, during the late rainy and dry seasons, respectively. The tabanid flies include: Tabanus, Haematopota and Chriosops while the majority of muscids were Stomoxys.

Relatively higher mean catch (5.40) and higher apparent density (2.87) were obtained during the late rainy season than (2.37) and (1.26) in the dry season, the difference of which was statistically significant $(\mathrm{p}<0.05)$ (Table 2).

Table 2: The apparent density of tsetse flies in the late rainy and dry seasons

\begin{tabular}{llcccc}
\hline Seasons & $\begin{array}{l}\text { Tsetse flies } \\
\text { caught }\end{array}$ & $\begin{array}{c}\text { Total } \\
\text { caught }\end{array}$ & $\begin{array}{c}\text { Mean } \\
\text { caught }\end{array}$ & $\begin{array}{c}\text { Apparent } \\
\text { density }\end{array}$ & 95\% CI \\
\hline Late rainy season & G.pallidipes & 89 & 1.98 & 1.05 & $0.08-3.09$ \\
& G.morsitans & 22 & 0.49 & 0.26 & $0.06-0.46$ \\
& G.fuscipes & 132 & 2.93 & 1.56 & $0.90-2.22$ \\
& Total & 243 & 5.40 & 2.87 & $0.04-5.77$ \\
Dry Season & G.pallidipes & 48 & 1.06 & 0.56 & $0.08-1.04$ \\
& G.morsitans & 9 & 0.20 & 0.11 & $0.03-0.19$ \\
& G.fuscipes & 50 & 1.11 & 0.59 & $0.34-0.84$ \\
& Total & 107 & 2.37 & 1.26 & $0.45-2.07$ \\
\hline
\end{tabular}

Mean catches $=$ fly/trap, Apparent density $=$ mean fly caught/trap/day

The apparent density of tsetse flies in late rainy season and in the dry season was $G$. pallidipes 1.05 fly/trap/day (95\% CI $=0.08-3.09), G$. m. submorsitans 0.26 (95\% CI $=0.06-0.46)$, G.f.fuscipes 1.56 fly/trap/day $(95 \% \mathrm{CI}=0.90-2.22)$, and $0.56 \mathrm{fly} / \mathrm{trap} /$ day $(95 \% \mathrm{CI}=0.08-1.04), 0.11 \mathrm{fly} / \mathrm{trap} / \mathrm{day}(95 \% \mathrm{CI}=0.03-0.19)$ and $0.59 \mathrm{fly} / \mathrm{trap} / \mathrm{day}(95 \% \mathrm{CI}=0.34-0.84)$, respectively, with a statistically significant difference $(p<0.05)$. The overall apparent densities of tsetse flies were found to be fly/trap/day $2.87(95 \% \mathrm{CI}=0.4-5.77 \%)$ and flay/tap/day 1.26 (95\% CI= 0.45-2.07\%) in late rainy and dry seasons, respectively (Table 2). G. f. fuscipes and $G$. pallidipes appears to be dominant during the course of the study period, where as the apparent density of G. m. submorsitans was lower than G. pallidipes and G. f. fuscipes. 
A higher number of tsetse flies were caught during late rainy season, and there was statistically significant difference between seasons in the apparent density of tsetse $(p<0.05)$. Also the apparent densities of biting flies were significantly higher $(\mathrm{p}<0.05)$ in late rainy season $(1.49 \mathrm{fly} /$ trap/day, $18.66 \mathrm{fly} /$ trap/day $)$ than in the dry season (0.77 fly/trap/day, 15.04 fly/trap/day) for tabanids and muscids, respectively, and the overall apparent densities of biting flies were found to be $20.15 \mathrm{fly} /$ trap/day ( $95 \% \mathrm{CI}=14.23-26.03 \%$ ), and $15.81 \mathrm{fly} /$ trap/day $(95 \% \mathrm{CI}=10.86-20.75 \%)$ in late rainy and dry seasons, respectively.

The mean catch of tsetse flies caught between late rainy and the dry seasons was statistically significantly different $(p<0.05)$ (Table 3$)$.

Table 3: Total tsetse and species caught during late rainy and dry seasons in the study area

\begin{tabular}{lcccc}
\hline Season & \multicolumn{3}{c}{ Total tsetse flies caught } & Total percentage \\
\cline { 2 - 4 } & G.p & G.m.m & G.f.f & \\
\hline Late rainy & 89 & 22 & 132 & $243(69.43 \%)$ \\
Dry season & 48 & 9 & 50 & $107(30.57 \%)$ \\
Total & $137(39.14 \%)$ & $31(8.85 \%)$ & $182(52 \%)$ & $350(100 \%)$ \\
\hline
\end{tabular}

G.p. = Glossina pallidipes, G. m .m. = Glossina morsitans, G. f . f. = Glossina fuscipes

Observation of male and female tsetse: A total of 350 tsetse flies 243 and 107 were caught during the late rainy and the dry seasons, respectively, were subjected for sexing in the late rainy season 97 males (39.91\%) and 132 females $(60.08 \%)$ were observed while in the dry season 37 males (34.57\%) and 70 females $(65 \%)$ were observed with a significant statistical difference $(p<0.05)$ between the two sexes in both seasons.

Dissection of tsetse flies: Out of a total of 58 tsetse flies dissected (G.pallidipes 19, G.m.submorsitans 11, and G.fuscipes 28), 24 (41.38 \%) were found to be infected with trypanosomes. The infection rates for $T$. conglense were more frequent 17 (70.83\%) than T. vivax 7 (29.17\%).

Higher infection rates were observed in G. pallidipes (66.66 \%) followed by $G$. m. submorsitans (50\%) and G. f. fuscipes (25\%) in the late rainy season. In the dry season $57 \%, 40 \%$ and $25 \%$, infection rates were recorded for G.pallidipes, $G$. m. submorsitans and G. f. fuscipes, respectively. In both seasons G. pallidipes appeared to be the active transmitter of the disease in the study area. The overall infection rates recorded by dissection were $44.12 \%$ and $37.5 \%$ in the late rainy and in the dry season, respectively. 


\section{Parasitological studies}

Out of 600 cattle examined, $33.5 \%$ were found to be infected with trypanosomes while infection due to $T$. congolense was higher (61.19\%) compared to that due to T. vivax (34.32\%) (Table 4).

Table 4: Prevalence and trypanosome species identified in the late rainy and dry seasons in the study area

\begin{tabular}{lcccccc}
\hline Season & Total & Total & \multicolumn{3}{c}{ Prevalence rate (\%) and trypanosome species } \\
\cline { 5 - 7 } & Infected & sampled & T. c (\%) & T. v (\%) & Mixed (\%) & Prevalence \\
\hline Late rainy & 201 & 600 & $123(20.5)$ & $69(11.5)$ & $9(1.5)$ & $33.5 \%$ \\
Dry season & 106 & 600 & $62(10.66)$ & $36(6)$ & $8(1.33)$ & $17.83 \%$ \\
Total & 307 & 1200 & $185(15.58)$ & $105(8.75)$ & $17(1.42)$ & $25.66 \%$ \\
\hline
\end{tabular}

$T$. $c=T$. congolense, $T . v=T$. vivax; Mixed refers $=T$. congolense and T. vivax

The risk of infection with trypanosomes during the dry season was lower than the late rainy season, with a statistically significant difference for $T$. congolense infection in both seasons $(\mathrm{p}<0.05)$; where as there was no statistically significant difference observed in mixed infection T. congolense and T. vivax) $(\mathrm{p}>0.05)$.

During the late rainy season the prevalence of trypanosomosis infection in male cattle was $33.495 \%(95 \% \mathrm{CI}=0.22-0.56)$ and $33.5 \%(95 \% \mathrm{CI}=0.13-0.30)$ for female and the difference was not significant difference $(\mathrm{p}>0.05)$ (Table 4). Similarly, the prevalence of trypanosomosis infection was $17.72 \%(95 \% \mathrm{CI}=$ $0.36-0.90)$ for male and $17.55 \%(95 \% \mathrm{CI}=0.95-1.05)$ for female during the dry season, there is also statistically not significant difference $(p>0.05)$ between sex groups. In both seasons the prevalence of trypanosomosis in sexes groups was proportionally the same. But the prevalence of trypanosomosis infection between the late rainy season $(33.5 \%, 95 \% \mathrm{CI}=0.68-1.71)$ and the dry season $(17.64 \%, 95 \% \mathrm{CI}=0.24-0.62)$ was significantly different $(\mathrm{p}<0.05)$.

Table 5: Prevalence of trypanosomosis in male and female cattle during the late rainy and in the dry seasons

\begin{tabular}{llcccccc}
\hline Season & \multirow{2}{*}{$\begin{array}{c}\text { Sex } \\
\text { groups }\end{array}$} & \multirow{2}{*}{$\begin{array}{c}\text { Total } \\
\text { Infected }\end{array}$} & \multirow{2}{*}{$\begin{array}{c}\text { Total } \\
\text { sampled }\end{array}$} & \multicolumn{3}{c}{ Trypanosome species identified } \\
\cline { 7 - 8 } Late & Male & 138 & 412 & 85 & 47 & 6 & $33.495 \%$ \\
rainy & Female & 63 & 188 & 38 & 22 & 3 & $33.510 \%$ \\
& Total & 201 & 600 & 123 & 69 & 9 & $33.5 \%$ \\
\multirow{2}{*}{ Dry season } & Male & 73 & 412 & 43 & 25 & 5 & $17.72 \%$ \\
& Female & 33 & 188 & 19 & 11 & 3 & $17.55 \%$ \\
& Total & 106 & 600 & 62 & 36 & 8 & $17.64 \%$ \\
\hline
\end{tabular}

$T . c=T$. congolense, $T . v=T$. vivax $;$ Mixed refers $=T$. congolense and T. vivax 
In the late rainy season higher infection rate was observed in older animals $(>4$ years) with a percentage of $31 \%(95 \% \mathrm{CI}=0.84-1.19)$ than calves $(<1$ year old) with a value of $21 \%$ (95\% CI= 0.11-0.30) the difference of which was significant $(\mathrm{p}<0.05)$ (Table 6).

Table 6: Prevalence of trypanosomosis in different age groups of cattle in the late rainy and dry seasons

\begin{tabular}{|c|c|c|c|c|c|c|c|}
\hline \multirow[t]{2}{*}{ Season } & \multirow[t]{2}{*}{ Age group } & \multirow{2}{*}{$\begin{array}{c}\text { Total } \\
\text { Infected }\end{array}$} & \multirow{2}{*}{$\begin{array}{c}\text { Total } \\
\text { sampled }\end{array}$} & \multicolumn{4}{|c|}{ Trypanosome species diagnosed } \\
\hline & & & & T. c & T. v & Mixed & Prevalence \\
\hline \multirow{4}{*}{$\begin{array}{l}\text { Late } \\
\text { rainy }\end{array}$} & $<1$ year & 16 & 75 & 5 & 9 & 1 & $21 \%$ \\
\hline & 1-4 years & 57 & 197 & 39 & 15 & 4 & $29 \%$ \\
\hline & $>4$ years & 101 & 328 & 59 & 36 & 6 & $31 \%$ \\
\hline & Total & 174 & 600 & 102 & 61 & 11 & $27 \%$ \\
\hline \multirow{4}{*}{$\begin{array}{l}\text { Dry } \\
\text { season }\end{array}$} & $<1$ year & 12 & 75 & 4 & 7 & 1 & $16 \%$ \\
\hline & 1-4 years & 44 & 197 & 24 & 18 & 2 & $22 \%$ \\
\hline & $>4$ years & 77 & 328 & 52 & 22 & 3 & $24 \%$ \\
\hline & Total & 133 & 600 & 80 & 47 & 6 & $21 \%$ \\
\hline
\end{tabular}

In the dry season relatively, lower infection was observed in calves ( $<1$ year old) $16 \%(95 \% \mathrm{CI}=0.17-0.47)$ and in adult animals $(1-4$ years old) $22 \%(95 \% \mathrm{CI}=$ 1.51-2.02) than older animals ( $>4$ years old) $24 \%$ (95\% CI= 2.8-3.2). However, the difference in prevalence among age groups was not significant $(p>0.05)$.

\section{Hematological finding}

The PCV value of cattle was significantly $(\mathrm{p}<0.05)$ influenced by trypanosome infection. The mean PCV (\%) values of parasitaemic and aparasitaemic animals during the late rainy season was $20.19 \%(95 \% \mathrm{CI}=18.72-21.64)$ and $26.75 \%$ (95\% CI=25.34-26.18) while during the dry season $18.75 \%$ (95\% CI=17.85$19.63)$ and $23.97 \%(95 \% \mathrm{CI}=23.52-24.40)$ respectively. There was a statistically significant difference in mean PCV values between seasons $(\mathrm{p}<0.05)$ (Table 7).

Table 7: Mean PCV (\%) values of parasitaemic and aparasitaemic cattle in late rainy and dry seasons in the study area

\begin{tabular}{lll}
\hline Season & Mean PCV value of parasitaemic & Mean PCV value of aparasitaemic \\
\hline Late rainy & $20.19 \%(95 \% \mathrm{CI}=18.72-21.64)$ & $26.75 \%(95 \% \mathrm{CI}=25.34-26.18 \%)$ \\
Dry season & $18.75 \%(95 \% \mathrm{CI}=17.85-19.63)$ & $23.97 \%(95 \% \mathrm{CI}=23.52-24.40)$ \\
Overall & $19.47 \%(95 \% \mathrm{CI}=18.85-19.98)$ & $25.36 \%(95 \% \mathrm{CI}=24.95-25.66)$ \\
\hline
\end{tabular}

The overall mean PCV values were also significantly different between parasitaemic and aparasitaemic animals $19.47 \%(95 \% \mathrm{CI}=18.85-19.98)$ and 
$25.36 \%$ (95\% CI=24.95-25.66 ( $<<0.001)$, respectively. The range of PCV values in parasitaemic animals was from $10-32 \%$ and in aparasitaemic animals was from $12-38 \%$ in the late rainy season while in the dry season was from $10-24 \%$ in parasitaemic animals and $11-35 \%$ in aparasitaemic animals.

\section{Discussion}

The results of questionnaire survey revealed that trypanosomosis is the most important problem for agricultural activity and animal production in the study area. Nega Twelde (2001) and Yohannes Afework (1998) reported the same finding in Western and Northern parts of the country. Even though trypanosomosis occurs throughout the year, major infections are observed during the late rainy season. Similar results were reported by Yohannes Afework (1998), Ngare and Muendia (2000) and Nega Tewelde, (2001). Absence of integrated tsetse control activity in the study area generally made the farmers dependable on the use of chemotherapy.

Most of the respondents have been using chemotherapy based on trypanocidal drugs, as a sole means of control and managing the disease. About $35 \%$ of the respondents have shown that they were using different types of trypanocidal drugs buying them from illegal traders on market days. Lack of tsetse control activities in the area encouraged farmers to embark on self use of chemotherapy. A survey conducted in West Africa (Bauer, 2001) indicated similar findings where trypanocidal drugs were used for over $90 \%$ of all cases without proper diagnosis.

The questionnaire survey result also indicated that the available trypanocidal drugs in the study area used by farmers were Diminazine aceturate and Isometamidium chloride and the required dosage for the treatment was not properly known by most of the respondents and they didn't have any idea about the sites of administration. Analogous results were reported by Yohannes Afework (1998) and Nega Tewelde (2001) and may be responsible for development of drug resistance in the area.

The significantly higher fly catch $(\mathrm{P}<0.05 \%)$ was observed during late rainy season than the dry season. These findings suggest that rainfall and temperature favoured fly production and activities as previously reported by Takle Sori (2006) in settlement area of Nono district, Southwest Ethiopia. Three species of tsetse, namely G. pallidipes, G. m. submorsitans and G. f. fuscipes were detected in this study. Similar reports were indicated in the results of by Terzu Daya (2004) and Takele Sori (2006). 
The present study revealed that the apparent tsetse density varies significantly between seasons in parallel with the risk of trypanosomosis. A high tsetse apparent density during the wet season has been reported in Somalia (Mohammad and Diarri, 1987), in Coted'Ivore, Togo, Gabon and Zaire (Leak et al., 1987) and in Ethiopia (Msangi, 1999). The level of infection rate is determined by the density of tsetse fly population in the area and the level of their contact with the host. This is further influenced by the vectoral capacity of the fly and availability of its preferred host, which is not necessarily domestic livestock (Radostits et al., 2000).

Sex ratio and age composition of the flies were assessed and a higher number of female and adult flies were recorded during the present study. According to Msangi (1999), Mohamed and Diarri (1987) and Leak (1999) showed female flies would comprise $70-80 \%$ of the mean population. The high proportion of female is most probably attributed to the fact that they live longer (mean

female fly life span being eight weeks, but only four weeks in males); hence more females could be caught as reported by Leak et al (1987) and Terzu Daya (2004).

In this study, biting flies such as tabanids and mucids were caught from both tsetse infested and tsetse free areas however the most frequently observed biting fly was Stomoxys. Similar observations were seen in different countries like Burkina Faso and Mauritania (Dia et al., 1998; Acapovi et al., 2001). Generally the apparent density of tsetse flies and other biting flies were significantly higher during the late rainy season as compared to the dry season in the present survey. Similar findings reports were reported in previous works (Msangi, 1999; Terzu Daya, 2004 and Takele Sori, 2006). This could be explained by an absolute increase in the number of flies due to favorable environment such as enough moisture, vegetation growth and suitable habitat. In another study Bright well et al., (1992) and Leak et al (1993) reported that the spread of flies from riversides and thickets, where they usually inhabit during the dry season and during the rainy season they increases relative density to more an open areas.

The highest prevalence of trypanosomosis observed in the present study was found to be in agreement with the previous studies. The most prevalent trypanosome species in tsetse infested areas of Ethiopia are T. congolense, T. vivax and T. brucei. Rowlands et al., (1993) reported a prevalence of $37 \%$ for T. congolense, in Southwest Ethiopia. Similarly Getachew Abebe and Yilma 
Jobre (1996) reported an infection rate of $58 \%$ for $T$. congolense, $31.20 \%$ for T. vivax and $3.5 \%$ for T. brucei in Southwest Ethiopia. In the same report it was also reported that $8.71 \%$ prevalence was recorded in the high lands of tsetse free area of which $99 \%$ was due to T.vivax. In Metekel district, different workers (Yohannes Afework, 1998; Muturi, 1999; Nega Tewelde, 2001) reported prevalence of $17.2 \%$ and $17.5 \%$ in the upper Didessa valley and southern rift valley areas of tsetse infested regions, respectively, where the dominant species was $T$. congolense.

In the present study, there was higher prevalence of trypanosomosis in both the dry (17.66\%) and late rainy (33.5\%) seasons; however, the difference between them was statistically significant $(p<0.05)$. Similar results were reported by Muturi (1999) in North Omo Zone. This might be attributed to the difference in tsetse apparent density and infection rates in both seasons. It is known that the risk of trypanosomosis is influenced by tsetse apparent density and infection rate in flies. Riordan (1977) demonstrated that a high tsetse apparent density and infection rate of $50 \%$ in tsetse results $42 \%$ trypanosome prevalence in cattle exposed to tsetse flies.

The dominant species in this study was $20.5 \%$ and $11.5 \%$ for T. congolense, and $10.6 \%$ and $6 \%$ for $T$. vivax during the late rainy and in the dry season, respectively. The same trend is also reported by Rowlands et al., (1995) that was T. congolense (66.17\%) followed by T. vivax (20.8\%) in Southern Rift Valley of Ethiopia during the late rainy season. In Ghibe prevalence 84\% and $14 \%$ was recorded for $T$. congolense and T. vivax, respectively (Muturi, 1999., Rowlands et al., 1995). In Northwestern and Southwestern Ethiopia the dominant species was T. congolense (Getachew Abebe and Yilma Jobre, 1996; Yonannes Afework, 1998; Nega Tewelde, 2001). The predominance of $T$. congolense infection in cattle may be due to the high number of serodems of $T$. congolense as compared to T. vivax and the development of better immune response to $T$. vivax by the infected animal (Leak et al., 1999).

In this study a higher infection rate was observed in adult animals and animals above one year of age. This could be associated to the fact that animals travel long distance for grazing and draught as well as harvesting crops in areas of high to tsetse challenge. In the results of Rowlands et al (1995), in Ghibe valley indicated that suckling calves don't go out with their dams but graze at homesteads until they are weaned off. Young animals are also naturally protected to some extent by maternal antibodies (Fimmen et al., 1992). This could result in low prevalence in calves and also T. congolense infection is a 
chronic disease increasing with age of animals. Infection by $T$. congolense is usually higher in adult animals than young (Mc Dermott et al., 2003).

In the present finding significant differences $(\mathrm{p}<0.05)$ in PCV values for parasitaemic (19.47\%) and aparasitaemic (25.36\%) cattle was observed. Similar trends of mean PCV values were reported by other researches (Yohannes Afework, 1998; Muturi, 1999; Nega Tewelde, 2001). The results by Muturi (1999) indicated the mean PCV values of $16.7 \%$ and $28.0 \%$ in North Omo Zone; Feyisa Regassa (2004) reported $21.65 \%$ and $25.54 \%$ in southwest Ethiopia; Takele Sori (2006) reported $20.22 \%$ and $27.23 \%$ in East Wollega Zone, Tilahun Tekle (2007) recorded $18.8 \%$ and $24.8 \%$ in Nono district of Oromia region for parasitaemic and aparasitaemic cattle, respectively.

In this study, trypanosome infection and mean PCV values obtained between parasitaemic and aparasitaemic animals had statistically significant difference. This was in agreement with the previous work done in Ghibe valley, Southwest Ethiopia where treatment was given for animals with PCV value of less than $26 \%$ and for positive animals. Rowlands et al (2001) indicated that in an increased PCV value, the proportion of positive cases will decrease and hence mean PCV was a good indicator for the health status of the herd in an endemic area and cattle with mean PCV values less than $26 \%$ were considered as anaemic which is said to be the principal sign of trypanosomosis. In this study, $81.6 \%$ of all parasitaemic animals had a mean PCV below $26 \%$ which agrees with different works (Rawlands et al., 1995; Abebe and Jobre, 1996; Afework, 1998; Muturi, 1999).

The present study indicated that trypanosomosis is a major constraint limiting agricultural activity and a serious threat for animal production and utilization of the fertile land in the study area. The situation is getting worse as the control and prevention of trypanosomosis is facing a challenge due to limitation of vector control activities. Control strategies should be centered on the community based; sustainable, cost effective and environmentally affable integrated approaches. 


\section{References}

Abebe, G., 2005. Trypanosomosis in Ethiopia. Ethio, J. Bio. Sci, 4, 75-121.

Abebe, G. and Jobre, Y., 1996. Trypanosomosis: A Threat to cattle production in Ethiopia Rev. Med. Vet., 147, 896-902.

Acapovi, G. L., Yao, Y, Goran, E. N., Dia, M. L. \& Desquesnes, M., 2001. Relative abundance of tabanids in the savannah regions of Cote d' Ivôire. Revue d'Eleavge et de Médéecine Veterinaire des pays Tropicaux, 54 , 109 - 114.

Afework, Y., 1998. Field investigation on the appearance of drug resistant population of trypanosomes in metekel district, Northwest Ethiopia. M.Sc. Thesis, Addis Ababa University and Freiuniverstat Berlin, Faculty of veterinary medicine, Ethiopia.

Afework, Y., Clausen, P. H., Abebe, G., Tilahun, G. and Mehlitz, D., 2000. Appearance of multiple-drug resistant Trypanosoma congolense populations in village cattle of Metekel district, North-west Ethiopia, Acta Trop., 76, 231-238.

ARDOSWSHZ, (2007): Agricultural and Rural Development of Southwest Shoa Zone. Annual report. pp 14-16.

Bauer, B. 2001, Improved strategies for sustainable trypanosomosis management within the context of primary animal health care. In: Proceeding of the international Scientific Council for trypanosomosis Research and control (ISCTRC), Mombasa, Kenya. No.120, 123-130.

Bourn, D. M., Reid, R.S., Rogers, D. J., Shnow W. F. and Wint, G. R.W. 2001. Environmental Change and the Autonomous control of tsetse and trypanosomosis in sub-Saharan Africa: case histories from Ethiopia, Gambia, Kenya, Nigeria and Zimbabwe. Oxford: Environmental Research Group Oxford Limited. pp. 9-24.

Brightwell, R., Dransfield, R. D., Korku, C. A., Golder, T. K., Tarimo, S. A. and Mugnai, D. 1992. A new trap for Glossina pallidipes. Tropical pest management, 33, 151159.

Dia, M.L., Diop, C. , Elsen , P., Cuisance, Th iam, A. \& Chollet, J. Y. 1998. Abundance and seasonal variations of tabanids in southern Mouritania. Ann. N.Y. Acad. Sci. 849, $456-460$.

Feyisa, R. 2004. Current epidemiological situation of bovine trypanosomosis in Limu Shay tsetse controlled area of Upper Didessa valley. MSc thesis, Addis Ababa University, Faculty of Veterinary Medicine, Debre-Zeit, Ethiopia. 
Fimmen, H. O., Mehlitz, D., Horchiner, F., Korb, E. 1992. Colostral antibodies and Trypanosoma congolense infection in calves. Trypanotolerance research and application. GTZ, No.116, Germany. pp. 173-187.

Leak, S. K. A., Woume, K. A., Collardelle, C., Duffera, W., Feron, A., Mulingo, M., Tikubet, G., Toure, M., and Yangari, G. 1987. Determination of tsetse challenge and its relationship with trypanosomosis prevalence. Livestock production in tsetse infested areas of Africa, ATLN, 1987, 43-52, Nairobi, Kenya.

Leak, S. G. A., Mulatu, W., Authie, E., Perergrine, A. S., Rowlands, G. J., Trail, J. C. M. 1993. Tsetse challenge and its relationship to trypanosomosis prevalence in cattle. Acta Trop., 53, 121-134.

Leak, S. G. A. 1999. Tsetse Biology and Ecology: Their role in the epidemiology and control of trypanosomosis. CABI Publishing in association with the ILRI. pp. 152 210.

Mc Demott, J. J., Woitag, T., Sidibe, I., Bauer, B., Boucader, D., Ouedrago, D., Kamuanga, M., Peregrine, A. S., Eisler, M. C., Zessin, K. H. 2003. Field studies on drugs resistant animal trypanosomosis in Kenedogou province, Burkina faso. Acta. Trop. 86, 93-103.

Msangi, S. 1999. Distribution, density and infection rates of tsetse flies in selected sites of southern Rift valley of Ethiopia. MSc thesis, Addis Ababa University, Faculty of Veterinary Medicine, Debre-Zeit, Ethiopia and Freie Universitat Berlin.

MOA, 1995. Ruminant Livestock Development Strategy (RLDS), Ministry of Agriculture, Addis Ababa, Ethiopia. pp.10.

Msangi, S. 1999. Distribution, Density and Infection rates of tsetse flies in selected sites of Southern Rift valley of Ethiopia. MSc thesis, Addis Ababa University Faculty of Veterinary Medicine, Debre Zeit, Ethiopia and Freie Universitat Berlin.

Murray, M.; Murray, P. K and Mc Intyre, W. I. M. 1977. An improved parasitological technique for the diagnosis of African trypanosomosis. Trans. R. Soc. Trop. Med. Hyg. 71, 325-326.

Muturi, K.S. 1999. Epidemiology of bovine trypanosomosis in selected sites of the Southern Rift valley of Ethiopia. MSc thesis, Addis Ababa University, Faculty of Veterinary Medicine, Debre-Zeit, Ethiopia. 
Ngare, P. M. and Muendia, C. M. T. 2000. Tsetse and trypanosomosis: An epidemiological survey in Osupuko and Mara division of Narok district. International Scientific Council for Trypanosomosis Research and Control. 25 th meeting, Mombassa (Kenya), 25 Sep-1 Oct. 1999.

OARDB, (2005): Oromia Agricultural and Rural Development Bureau. Annual Report. pp 25-28.

Radostits, O. M.; Blood, D. C. and Gay, C. C. 2000. Veterinary Medicine, A Textbook of the Diseases of cattle, sheep, pigs, goats and horses, $8^{\text {th }}$ ed. By Bailliere Tindall. pp. 1212-1221.

Riordan, K. 1977. Long term variations in trypanosome infection rates in highly infected tsetse flies on a cattle route in Southwest Nigeria. Annual Tropical Medicine and parasitology, 71, 11-20.

Rowlands, G. J., Mulatu, W., Authie, E., Leak, S. G. A and Peregrine, A. S. 1993. Epidemiology of bovine trypanosomosis in the Ghibe valley, Southwest Ethiopia. Acta Trop. 53, 135-150.

Rowlands, G. J., Mulatu, W., Nagda, S. M., Dolan, R. B., d’Ieteren, G. D. M. 1995. Genetic variation in packed red cell volume and frequency of parasitaemia in East African Zebu cattle exposed to drug resistant trypanosomes. Livestock Production Science. 43, 75-84.

Rowlands, G. J., Leak, S. G. A., Peregrine, A. S., Nagda, S. M., Mulatu, W., d'Teteren, G. D. M. 2001. The incidence of new and the prevalence of recurrent trypanosome infection in cattle in Southwest Ethiopia exposed to a high challenge with drug resistant parasite. Acta trop. 79, 149-163.

Takele, S. 2006. Epidemiology of bovine trypanosomosis in three selected sites of the newly established settlement areas of Sassiga district, in East Wollega Zone, Oromia National Regional State, Western Ethiopia. MSc thesis, Addis Abeba University, Faculty of Veterinary Medicine, Debre-Zeit, Ethiopia. pp.1-87.

Tekle, T. 2007. Epidemiology of bovine trypanosomosis in the newly established settlement area of Nono district, southwest Ethiopia. MSc thesis, Addis Ababa University, Faculty of Veterinary Medicine, Debre-Zeit, Ethiopia. pp. 1-75.

Terzu, D. 2004. Seasonal dynamics of tsetse and trypanosomosis in selected sites of Southern Nation and Nationalities and peoples Regional State. MSc thesis, Addis Ababa University, Faculty of Veterinary Medicine, Debre-Zeit, Ethiopia. pp.1-80. 
Tewelde, N. 2001. Study on the occurrence of drug resistant trypanosomes in cattle in the farming in tsetse control areas (FITCA) project in Western Ethiopia. MSc thesis, Addis Ababa University, Faculty of Veterinary Medicine, Debre-Zeit, Ethiopia.

Tewelde, N., Abebe, G., Mc Dermountt, J.J., Eslier, M.C., Greiner, M., Afework, Y., Kyule, M., Munestermann, S., Zessin, K.-H and Clausen, P.H. 2004. Application of field methods to assess Isometamidium resistance of trypanosomosis in cattle in western Ethiopia. Acta. Trop., 90, 163-170.

Thrusfield, M. 1995. Veterinary Epidemiology. Second edition 1995 published by Blackwell Science Ltd., pp. 178-198. 
